\title{
ORGANIZATIONAL CITIZENSHIP BEHAVIOR DITINJAU DARI KEPUASAN KERJA
}

\author{
Sarimonang Sihombing ${ }^{1}$ \\ Darna Sitanggang ${ }^{2}$ \\ ${ }^{1}$ Dosen Program Studi Manajemen Universitas Katolik Santo Thomas. \\ sarimonangsihombing@gmail.com \\ ${ }^{2}$ Dosen Program Studi Manajemen Universitas Katolik Santo Thomas. \\ darna.sitanggang@gmail.com
}

\begin{abstract}
Abstrak
Organizational Citizenship Behavior (OCB) merupakan kontribusi individu yang melebihi tuntutan peran di tempat kerja dan di-reward oleh perolehan kinerja tugas.Organisasi yang memiliki karyawan denganOrganizational Citizenship Behavior yang baik, akan memiliki kinerja yang lebih baik dari organisasi yang lain.Perilaku ini muncul karena perasaan sebagai anggota organisasi dan merasa puas apabila dapat melakukan sesuatu yang lebih kepada organisasi. Organizational Citizenship Behavior(OCB) ini melibatkan beberapa perilaku meliputi perilaku menolong orang lain, menjadi volunteer untuk tugas-tugas ekstra, patuh terhadap aturan-aturan dan prosedurprosedur di tempat kerja. Dimensi Organizational Citizenship Behavior adalah perilaku membantu,kepatuhan terhadap organisasi,sportmanship, loyalitas terhadap organisasi, inisiatif individual, kualitas sosial dan perkembangan diri. Faktor-faktor yang mempengaruhi Organizational Citizenship Behavior antara lain: merasa puas dengan pekerjaannya, menerima perlakuan yang sportif dan penuh perhatian dari pengawas dan percaya bahwa mereka diperlakukan adil dalam organisasi.Salah satu faktor yang mempengaruhi meningkatnya perilaku Organizational Citizenship Behavior dalam suatu organisasi adalah faktor yang berasal dari dalam diri karyawan, seperti kepuasan kerja. Faktor-faktor yang mempengaruhi kepuasan kerja antara lain: faktor hubungan antra karyawan, faktor-faktor individual dan faktor-faktor luar seperti rekreasi dan pendidikan. Dimensi kepuasan kerja antara lain: kepuasan dalam pekerjaan itu sendiri, gaji, pengakuan, hubungan antara supervisor dengan tenaga kerja dan kesempatan untuk maju.
\end{abstract}

Kata Kunci: OCB, Kepuasan Kerja.

\section{PENDAHULUAN}

Keberhasilan sebuah organisasi sangat ditentukan oleh perilaku orang-orang yang ada dalam organisasi tersebut. Perilaku-perilaku pekerja secara konseptual dibedakan sebagai in-role (task dependent behavior) dan extra- role. Perilaku in-role yaitu melakukan pekerjaan sesuai dengan tugas yang ada dalam job description,sedangkanextra role, yaitu perilaku individu yang melebihi standar perilaku yang diharapkan. Perilaku in-role yang dilakukan karyawan dihubungkan dengan penghargaan ekstrinsik atau penghargaan moneter, dimana apabila karyawan selalu berperilaku 
sesuai aturan yang ada dan melaksanakan tugasnya dengan benar, maka yang bersangkutan akan diberi penghargaan baik berupa insentif ataupun bentuk lain seperti promosi jabatan. Sedangkan perilaku extra-role lebih dihubungkan dengan penghargaan intrinsik. Perilaku ini muncul karena perasaan sebagai "anggotá" organisasi dan merasa puas apabila dapat melakukan "sesuatu yang lebih" kepada organisasi, bukan karena mengharapkan bentuk imbalan moneter sebagaimana halnya dalam perilaku in-role.

Kartz (dalam Sumyarsih, 2012) , menekankan bahwa perilakuperilaku koperatif dan saling membantu yang berada di luar persyaratan formal sangat penting bagi berfungsinya organisasi. Perilaku tambahan diluar deskripsi pekerjaan dalam organisasi sering disebut sebagai perilaku kewarganegaraan dalam organisasi atau Organizational Citizenship Behavior (OCB).Organizational Citizenship Behavior (OCB) yaitu aturan tidak resmi yang bersifat sukarela. Dengan adanya OCB diharapkan karyawan pada organisasi dapat lebih menyatu dengan lingkungan kerjanya. Organizational Citizenship Behavior $(O C B)$ adalah perilaku yang dilakukan karyawan yang meningkatkan keefektifan organisasi tetapi bukan merupakan tanggung jawab formal orang tersebut, Hanson dan Borman, 2006 (dalam King, 2010). Setiap sistem sosial yang hanya mengandalkan diri pada rancangan baku suatu bentuk perilaku tertentu akan menjadi sangat rentan dan menyarankan perlunya suatu perilaku ekstra untuk menjamin kemampuan bertahan dan keberhasilan sistem sosial tersebut. Dengan demikian bukan hanya organisasi bisnis, seluruh sistem sosial akan mendapat manfaat yang sangat tinggi dari usaha-usaha ekstra yang diberikan oleh individu-individu dalam sistem sosial. Kepatuhan dan partisipasi karyawan terhadap organisasi dapat menentukan tinggi rendahnya OCB pada karyawan.

Organisasi yang berorientasi pada karyawan, memiliki angkatan kerja yang berdedikasi dan berkomitmen pada perusahaan sehingga mampu menciptakan produktifitas dan kepuasan karyawan yang lebih tinggi. Dengan kepuasan karyawan yang tinggi maka akan tercipta suasana kerja yang nyaman, dengan begitu karyawan akan bekerja melebihi kewajiban kerja biasa dan memberikan kinerja melebihi apa yang diharapkan, dan perilaku tersebut mampu meningkatkan efektifitas dan kelangsungan hidup organisasi. Seorang karyawan yang memunculkan perilaku Organizational Citizenship Behavior disebut sebagai karyawan yang baik atau good citizen. Contoh perilaku Organizational Citizenship Behavior, antara lain, membantu rekan kerja, melindungi properti 
organisasi, menghargai peraturan yang berlaku didalam suatu organisasi, toleransi pada situasi yang kurang ideal (situasi tidak menyenangkan), memberi saran-saran yang dapat membangun di tempat kerja serta tidak membuang-buang waktu di tempat kerja.

Antara organisasi profit dan non profit, keduanya membutuhkan karyawan yang berperilaku Organizational Citizenship Behavior, hal ini dikarenakan masing-masing organisasi harus bisa mempertahankan organisasinya di era globalisasi ini, dan mampu mewujudkan tujuan utama dari organisasi. Untuk itu, perlu diketahui, bagaimana caranya supaya karyawan suatu organisasi bersedia bekerja di luar tugas dan tanggung jawab formal yang ditetapkan organisasi.

Salah satu faktor yang memperngaruhi meningkatnya perilaku Organizational Citizenship Behaviordalam suatu organisasi adalah faktor yang berasal dari dalam diri karyawan, seperti kepuasan kerja.Kepuasan kerja merupakan sikap umum seorang individu terhadap pekerjaannya, seseorang dengan tingkat kepuasan kerja tinggi menunjukkan sikap yang positif terhadap pekerjaan itu. Seseorang yang tidak puas akan pekerjaannya menunjukkan sikap negatif terhadap pekerjaannya. Ruang lingkup manajemen sumber daya manusia secara umum membahas hal-hal berkaitan dengan manusiawi termasuk di dalamnya kepuasan kerja. Kepuasan yang dirasakan pegawai dalam bekerja merupakan suatu petunjuk bahwa pegawai memiliki perasaan senang dalam menjalankan tugasnya. Bagi organisasi, kepuasan kerja harus mendapat perhatian dan pemenuhan.

Kepuasan kerja bagi seorang pegawai merupakan faktor yang amat penting karena kepuasan yang diperolehnya akan turut menentukan sikap positif terhadap pekerjaan. Perasaan puas dalam bekerja dapat menimbulkan dampak positif terhadap perilaku, misalnya tingkat kedisiplinan dan semangat kerja yang cenderung meningkat.

Hal ini senada dengan pendapat Podsakoff (2000) bahwa ada empat faktor yang mendorong munculnya Organizatioanl Citizenship Behavior dalam diri karyawan. Ke empat faktor tersebut adalah karakteristik individual, karakteristik tugas/pekerjaan, karakteristik organisasional dan perilaku pemimpin

Kepuasan pegawai atas apa yang telah dilakukannya untuk kepentingan organisasi dan pribadinya perlu mendapat perhatian dari pimpinan, hal ini tidak lain agar pegawai dalam pencapaian tujuan melebihi apa yang diharapkan. Kepuasan kerja sebagai kelompok perasaan 
evaluatif tentang pekerjaan memiliki beberapa faktor pendorong pada diri seseorang.

Menurut Robbins (2008) kepuasan kerja dapat muncul karena kerja yang secara mental menantang, ganjaran yang pantas, kondisi kerja yang mendukung, rekan kerja yang mendukung, kesesuaian kepribadian dengan pekerjaan. Artinya, bahwa gaji bukanlah faktor yang mutlak mendasari seseorang merasa puas atau tidak puas.

Berdasarkan uraian di atas dapat disampaikan betapa pentingnya organisasi memiliki karyawan yang bersedia bekerja di luar batas deskripsi jabatan yang ada. Apabila karyawan bekerja dengan kerelaan sendiri maka hasil kerjanya akan lebih baik dan dengan sendirinya akan mendukung terhadap pencapaian tujuan organisasi dimana mereka bekerja. Supaya karyawan bersedia bekerja secara sukarela, maka karyawan perlu merasakan kepuasan dari lingkungan kerjanya, baik dari segi manajemen, rekan kerja, suasana kerja dan lain sebagainya. Situasi lingkungan kerja tersebut tidak terlepas dari dukungan manajemen, yang mampu menciptakan suasana kerja sesuai kebutuhan karyawan yang membuat karyawan merasa puas akan pekerjaannya, dan dengan demikian akan muncul perilaku kewarganegaraan dari diri karyawan atau Organizational Citizenship Behavior.

\section{PEMBAHASAN}

\section{Pengertian OCB (Organizational Citizenship Behavior)}

Organizational Citizenship Behavior merupakan bagian dari ilmu perilaku organisasi.

Organizational Citizenship Behavior(OCB) merupakan bentuk perilaku kerja yang biasanya tidak terlihat. Terdapat dua pendekatan terhadap konsep OCB yaitu OCB merupakan kinerja extra role yang terpisah dari kinerja in role atau kinerja yang sesuai deskripsi kerja. Pendekatan kedua adalah memandang Organizational Citizenship Behavior(OCB) ini dari prinsip filosofi politik. Pendekatan ini mengidentifikasi perilaku anggota organisasi dengan perilaku kewarganegaraan.

Keberadaan Organizational Citizenship Behavior(OCB) merupakan dampak dari keyakinan dan persepsi individu dalam organisasi terhadap pemenuhan hubungan perjanjian dan kontrak psikologis. Perilaku ini muncul karena perasaan individu sebagai anggota organisasi yang memiliki rasa puas apabila dapat melakukan sesuatu yang lebih dalam organisasi 
Oganizational Citizenship Behavior merupakan istilah yang digunakan untuk mengidentifikasikan perilaku karyawan, mengacu pada konstruk dari extra role behavior, didefenisikan sebagai perilaku yang menguntungkan organisasi, yang langsung dan mengarah pada peran pengharapan. Dengan demikian, Oganizational Citizenship Behavior merupakan perilaku yang fungsional, extra -role, proporsional, yang mengarahkan individu, kelompok atau organisasi.

Perilaku atau peranan yang dilakukan oleh karyawan sangat penting bagi suatu perusahaan. Berbagai pendapat yang mengemukakan tentang pentingnya perilaku karyawan yang mau bekerja melebihi deskripsi jabatan yang ada antara lain seperti dikemukakan Robbins(2008) yang menyatakan bahwa organisasi yang sukses membutuhkan karyawan yang akan melakukan lebih dari sekedar tugas formal mereka dan mau memberi kinerja yang melebihi harapan. Dalam dunia kerja yang dinamis seperti sekarang ini, dimana tugas semakin sering dikerjakan dalam tim, fleksibilitas sangatlah penting. Organisasi menginginkan karyawan yang bersedia melakukan tugas yang tidak tercantum dalam deskripsi mereka, seperti bersedia membantu rekan kerja yang beban tugasnya sangat banyak, bersedia bekerja di luar jam kerja apabila ada hal penting yang harus diselesaikan dan lain sebagainya. Menurut Robbins dan Judge (2008), fakta menunjukkan bahwa organisasi yang memiliki karyawan denganOrganizational Citizenship Behavior yang baik, akan memiliki kinerja yang lebih baik dari organisasi yang lain.Perilaku ini muncul karena perasaan sebagai "anggotá" organisasi dan merasa puas apabila dapat melakukan "sesuatu yang lebih" kepada organisasi.Organ (1988) mendefinisikan Organizational Citizenship Behavior sebagai perilaku individu yang bebas, tidak berkaitan secara langsung atau eksplisit dengan system reward dan bisa meningkatkan fungsi efektif organisasi. Organizational Citizenship Behavior (OCB)juga ditemukan sebagai alternatif penjelasan pada hipotesis "kepuasan berdasarkan kinerja".

Organizational Citizenship Behavior (OCB) merupakan kontribusi individu yang melebihi tuntutan peran di tempat kerja dan di-reward oleh perolehan kinerja tugas. Organizational Citizenship Behavior(OCB) ini melibatkan beberapa perilaku meliputi perilaku menolong orang lain, menjadi volunteer untuk tugas-tugas ekstra, patuh terhadap aturan-aturan dan prosedur-prosedur di tempat kerja. Perilaku-perilaku ini menggambarkan "nilai tambah karyawan" yang merupakan salah satu bentuk perilaku pro sosial, yaitu perilaku sosial yang positif, konstruktif dan bermakna membantu. 
Dari beberapa definisi di atas dapat disimpulkan bahwa Organizational Citizenship Behavior merupakan: 1. Perilaku yang bersifat sukarela, bukan merupakan tindakan yang terpaksa terhadap

hal-hal yang mengedepankan kepentingan organisasi. Dengan kata lain, merupakan :

1. kontribusi pekerja di atas dan lebih dari job description formal.

2. Perilaku individu sebagai wujud dari kepuasan berdasarkan kinerja tidak diperintahkan secara formal, tetapi dilakukan secara sukarela

3. Tidak berkaitan secara langsung dan terang-terangan dengan system reward yang formal tetapi merupakan perilaku individu sebagai wujud dari kepuasan berdasarkan performance, tidak diperintahkan secara formal dan memberi kontribusi pada keefektifan dan keefisienan fungsi organisasi.

\section{Dimensi-dimensi Organizational Citizenship Behavior (OCB)}

Organizational Citizenship Behavior (OCB) adalah suatu sikap diluar sikap formal / in role, yang bersifat positif dan dilakukan karyawan secara sukarela / extra role behavior, sikap tersebut berguna bagi perusahaan, untuk dapat terus meningkatkan produktivitas dan keberlangsungan hidup perusahaan. Arti kata citizenship akan membuat karyawan memiliki rasa tanggung jawab dan cinta terhadap pekerjaan, dan secara sukarela tanpa diawasi melakukan pekerjaannya, karyawan akan merasa memiliki perusahaan (sense of belonging).

Menurut Farh, et al dalam Organ et al, (2006) OCB dapat diidentifikasikan menjadi 5 dimensi, antara lain, Identification with company, Altruism toward colleagues, Conscientiousness, Interpersonal Harmony, dan Protecting Company Resources.

Identification with company, merupakan kegiatan karyawan yang aktif dalam aktivitas organisasi dan peduli terhadap kelangsungan hidup organisasi. Secara sukarela berpartisipasi, bertanggung jawab dan terlibat dalam mengatasi masalah-masalah organisasi demi kelangsungan organisasi, dengan cara mempertahankan reputasi perusahaan dan aktif dalam mengemukakan gagasannya, serta ikut mengamati lingkungan bisnis dalam ancaman dan peluang.

Altruism toward colleagues, dapat dilihat dari karyawan yang menunjukkan suatu pribadi yang lebih mementingkan kepentingan orang lain, Altruism toward colleagues, misalnya karyawan yang sudah selesai dengan pekerjaannya membantu karyawan lain dalam menghadapi pekerjaan yang sulit. 
Conscientiousness, merupakan suatu perilaku yang bersifat bebas menunjukkan upaya karyawan untuk bekerja di luar batas persyaratan dari perusahaan. Perilaku tersebut melibatkan kreatif dan inovatif secara sukarela untuk meningkatkan kemampuannya dalam bekerja, demi peningkatan organisasi, misalnya berinisiatif meningkatkan kompetensinya dengan bekerja keras, secara sukarela mengambil tanggung jawab diluar wewenangnya.

Interpersonal Harmony, merupakan perilaku yang bersifat bebas, dilakukan karyawan untuk tidak mengejar kebutuhan sendiri, dan hanya mengejar jabatan dan kekuasaan, yang dapat menyebabkan lemunduran bagi suatu perusahaan. Dimensi ini menunjukkan bahwa karyawan memprioritaskan kepentingan perusahaan di atas kepentingan pribadi, sebab kalau kepentingan perusahaan tercapai, maka kepentingan pribadi juga akan terpenuhi.

Protecting Company Resources, merupakan perilaku yang bersifat bebas, dilakukan karyawan untuk mematuhi peraturan perusahaan dalam penggunaan sumber daya yang ada dan menghindari penggunaan untuk kebutuhan sendiri. Dimensi ini menunjukkan bahwa karyawan berusaha menggunakan sumber daya perusahaan sebaik mungkin dan penggunaannya hanya untuk kepentingan perusahaan.

Podsakoff et al (2000) membagi Organizational Citizenship Behavior $(O C B)$ menjadi tujuh dimensi:

1. Perilaku membantu, yaitu perilaku membantu teman kerja secara sukarela dan mencegah terjadinya masalah yang berhubungan dengan pekerjaan. Dimensi ini merupakan komponen utama dari Organizational Citizenship Behavior(OCB). Organ (1998) menggambarkan dimensi ini sebagai perilaku altruism, pembuat/penjaga ketenangan dan menyemangati teman kerja. Dimensi ini serupa dengan konsep fasilitas interpersonal, perilaku membantu interpersonal, OCB terhadap individu (OCB -I) dan perilaku membantu orang lain.

2. Kepatuhan terhadap organisasi, yaitu perilaku yang melakukan prosedur dan kebijakan perusahaan melebihi harapan minimum perusahaan. Karyawan yang menginternalisasikan peraturan perusahaan secara sadar akan mengikutinya meskipun pada saat sedang diawasi. Dimensi ini serupa dengan konsep kepatuhan umum dan menaati peraturan perusahaan.

3. Sportmanship, yaitu tidak melakukan kompelin mengenai ketidak nyamanan bekerja, mempertahankan sikap positif ketika tidak dapat 
memenuhi keinginan pribadi, mengijinkan seseorang untuk mengambil tindakan demi kebaikan kelompok. Dimensi ini serupa dengan konsep menghargai perusahaan dengan tidak mengeluh.

4. Loyalitas terhadap organisasi, yaitu meletakkan perusahaan di atas diri sendiri, mencegah dan menjaga perusahaan dari ancaman eksternal, serta mempromosikan reputasi organisasi.

5. Inisiatif individual, merupakan derajat antusiasme dan komitmen akstra pada kinerja melebihi kinerja maksimal yang diharapkan. Dimensi ini serupa dengan konsep kerja pribadi dan sukarela mengerjakan tugas.

6. Kualitas sosial, sebagai tindakan keterlibatan yang bertanggung jawab dan konstruktif dalam proses politik organisasi, bukan hanya mengekspresikan pendapat mengenai suatu pemberian, tetapi mengikuti rapat dan tetap mengetahui isu yang melibatkan organisasi.

7. Perkembangan diri, meliputi keterlibatan dalam aktivitas untuk meningkatkan kemampuan dan pengalaman seseorang sebagai keuntungan bagi organisasi.

Dalam rangka untuk mendapatkan pemahaman lebih mendalam mengenai Organizational Citizenship Behavior (OCB) dalam konteks diluar budaya Amerika Serikat, dibandingkan dengan berbagai bentuk Citizenship Behavior di China. Ada 3 kesamaan konteks di China dengan Amerika, yaitu identification with company ( sama dengan civic virtue), altruism, conscientiousness. Sedangkan variabel courtesy dan spotmanship dihilangkan dan digantikan dengan dua buah variable yang lebih memiliki kedekatan dengan budaya di Asia, yaitu Interpersonal Harmony dan Protecting Company Resourcess.

Budaya timur (China) dianggap memiliki kedekatan kebudayaan dengan kebudayaan Indonesia. Contohnya, budaya yang lebih berorientasi pada keluarga dari pada sikap individual di Barat. Orang-orang dari budaya yang berbeda akan malihat nilai-nilai atau kepercayaan yang berbeda sesuai dengan sudut pandang mereka.

Organizational Citizenship Behavior (OCB) dihitung sebagai konsep penting yang dapat memberikan kontribusi terhadap efektifitas fungsi dan daya saing organisasi. Secara konsep ada beberapa alasan yang menyebabkan OCB mempengaruhi efektifitas organisasi, dalam Organ et al, (2006) dikemukakan beberapa manfaat OCB, yaitu:

Organizational Citizenship Behavior(OCB) dapat meningkatkan produktifitas tenaga kerja, menghemat sumber daya perusahaan, OCB dapat bekerja secara efektif, dalam mengkoordinasikan kegiatan antar anggota tim dan grup kerja lainnya, karyawan secara sukarela dan aktif 
dalam kelompok kerjanya dan mampu berkoordinasi dengan kelompok lainnya, OCB mampu membuat tempat bekerja menjadi lebih menarik sehingga meningkatkan kemampuan perusahaan untuk menarik dan mempertahankan karyawa yang berkualitas, OCB dapat meningkatkan stabilitas kinerja suatu organisasi, dapat meningkatkan kemampuan organisasi untuk beradaptasi terhadap lingkungan yang berubah, meningkatkan keefektifan organisasi dengan cara menciptakan modal sosial.

\section{Faktor-faktor yang mempengaruhi Organizational Citizenship Behavior}

Faktor-faktor yang mempengaruhi timbulnya Organizational Citizenship Behavior(OCB) cukup kompleks dan saling terkait satu sama lain. Diantara faktor tersebut akan dibahas antara lain, budaya dan iklim organisasi, kepribadian dan suasana hati (mood), persepsi terhadap dukungan organisasi, persepsi terhadap kualitas interaksi atasan-bawahan, masa kerja dan jenis.

- Budaya dan iklim organisasi

Menurut Organ (2006) terdapat bukti-bukti yang mengemukakan bahwa organisasi merupakan sesuatu kondisi awal yang utama yang memicu terjadinya OCB. Sloat (dalam Nomvliadi, 2007) berpendapat bahwa karyawan cenderung melakukan tindakan yang melampaui tanggung jawab kerja mereka apabila mereka:

- Merasa puas dengan pekerjaannya

- Menerima perlakuan yang sportif dan penuh perhatian dari pengawas

- Percaya bahwa mereka diperlakukan adil dalam organisasi

Iklim organisasi dan budaya organisasi dapat menjadi penyebab kualitas berkembangnya OCB dalam suatu organisasi. Di dalam iklim organisasi yang positif, karyawan merasa lebih ingin melakukan pekerjaannya melebihi apa yang telah disyaratkan dalam uraian pekerjaan dan akan selalu mendukung tujuan organisasi jika mereka diperlakukan oleh para atasan dengan sportif dan dengan penuh kesadaran serta percaya bahwa mereke diperlakukan secara adil oleh organisasi.

Konovsky dan Pugh (dalam Nomvliadi, 2007) menggunakan terori pertukaran sosial (social exchange theory) untuk berpendapat bahwa ketika karyawan telah puas terhadap pekerjaannya, mereka akan membalasnya.Pembalasan dari karyawan tersebut termasuk rasa memiliki (sense of belonging) yang kuat terhadap organisasi dan perilaku seperti organizational citizenship. 
- Kepribadian dan suasana hati, mempunyai pengaruh terhadap timbulnya OCB secara individual maupun kelompok. George (dalam Nomvliadi, 2007) berpendapat bahwa kemauan seseorang untuk membantu orang lain juga dipengaruhi suasana hati. Kepribadian merupakan suatu karakteristik yang secara relatif dapat dikatakan tetap, sedangkan suasana hati merupakan karakteristik yang dapat berubah-ubah. Sebuah suasana hati yang positif akan meningkatkan peluang seseorang untuk membantu orang lain. Meskipun suasana hati (sebagian) dipengaruhi oleh kepribadian, ia juga dipengaruhi oleh situasi, misalnya iklim kelompok kerja dan faktorfaktor keorganisasian.

Perilaku karyawan tidak terlepas dari atribut kepribadian, seperti yang dijelaskan oleh Robbins dan Judge (2008), atribut kepribadiannya adalah self monitoring. OCB adalah suatu sikap diluar sikap formal / in role, yang bersifat positif dan dilakukan karyawan secara sukarela / extra role behavior, sikap tersebut berguna bagi perusahaan, untuk dapat terus meningkatkan produktivitas dan keberlangsungan hidup perusahaan. Arti kata citizenship akan membuat karyawan memiliki rasa tanggung jawab dan cinta terhadap pekerjaan, dan secara sukarela dan tanpa diawasi melakukan pekerjaannya, karyawan akan merasa memiliki perusahaan (sense of belonging).

\section{Pengertian dan Teori Kepuasan Kerja}

Menurut Suwarno dan Donni Juni Priansa (2011), kepuasan kerja adalah cara individu merasakan pekerjaannya yang dihasilkan dari sikap individu tersebut terhadap berbagai aspek yang terkandung dalam pekerjaan. Pemahaman serupa juga dikemukakan oleh Wibowo (2011), yaitu kepuasan kerja adalah derajat positif atau negatifnya perasaan seseorang mengenai berbagai segi tugas-tugas pekerjaan, tempat kerja dan hubungan dengan sesama pekerja. Hani handoko (2000) berpendapat bahwa kepuasan kerja adalah keadaan emosional yang menyenangkan atau tidak menyenangkan dengan mana para karyawan memandang pekerjaan mereka.

Dari beberapa pernyataan di atas dapat disimpulkan bahwa kepuasan kerja adalah cerminan perasaan pekerja terhadap pekerjaannya. Maka agar organisasi dapat mencapai tujuan, pimpinan organisasi perlu memperhatikan faktor atau sumber-sumber kepuasan kerja para anggotanya. 
Banyak ahli yang mengemukakan teori yang berhubungan dengan kepuasan kerja, antara lain Maslow, Alferder, Herzberg dan Mc Clelland.

a. Teori Maslow : Hirarki Kebutuhan

Maslow dalam Sigit (2003) mengatakan bahwa semua kebutuhan manusia yang banyak sekali itu dikelompokkan ke dalam lima kategori yang tersusun secara hirarki dari bawah ke atas yaitu kebutuhan phisiologis (physiological needs), kebutuhan keselamatan dan keamanan (safety and security needs), kebutuhan sosial (social needs), kebutuhan penghargaan (esteem needs), dan kebutuhan aktualisasi diri ( atau pengisian diri atau realisasi diri).

\section{b. Teori Alderfer : ERG}

Alderfer dalam Gibson (1994) menyatakan bahwa; dia setuju dengan pendapat bahwa setiap orang mempunyai kebutuhan yang tersusun dalam suatu hirarki. Akan tetapi hirarki kebutuhannya hanya meliputi tiga perangkat kebutuhan, yaitu eksistensi, keterkaitan dan pertumbuhan.

Menurut Alderfer dalam Sigit (2003) bahwa; "kebutuhan yang sudah terpuaskan pun dapat menjadi pendorong perbuatan, tidak seperti Maslow yang menyatakan bahwa kebutuhan yang belum terpuaskan saja yang mendorong terjadinya perbuatan atau perilaku". Dalam teori Alderfer dikenal adanya satisfaction - progression (maju karna puas) dan frustration - regression (mundur karena kecewa).

\section{c. Teori Dua Faktor Herzberg}

Herzberg menyatakan suatu teori yang berhubungan langsung dengan kepuasan kerja, yang didasarkan pada penelitian bersama Pittsburg dan sekitarnya. Dari hasil penelitian ini Herzberg dan Stoner menyatakan bahwa; "kepuasan kerja dan ketidak-puasan kerja berasal dari dua factor yang terpisah yang disebut factor pemberi kepuasan (factor motivator) dan factor pemberi ketidakpuasan (factor hygiene)".

Karyawan memiliki rasa kepuasan kerja dan rasa ketidak-puasan kerja dalam pekerjaannya, tetapi faktor-faktor yang menyebabkan kepuasan kerja berbeda jika dibandingkan dengan faktor-faktor yang menyebabkan ketidak-puasan kerja. Faktor-faktor yang menyebabkan terjadinya kepuasan kerja adalah pengakuan, tanggung-jawab, prestasi, pertumbuhan dan pengembangan serta pekerjaan itu sendiri, yang disebut sebagai faktor intrinsik. Sedangkan faktor-faktor yang membuat ketidakpuasan kerja adalah gaji, kedudukan, kondisi tempat kerja, perhubungan antar pribadi, penyeliaan, keselamatan kerja serta kebijakan dan 
administrasi perusahaan, dan faktor-faktor ini disebut faktor-faktor ekstrinsik.

\section{d. Teori Mc Clelland}

Mc Clelland dalam Gibson (1994) menyatakan bahwa; banyak kebutuhan yang diperoleh dari kebudayaan. Tiga dari kebutuhan yang dipelajari ini adalah kebutuhan berprestasi (need for achievement), kebutuhan berafiliasi (need for affiliation) dan kebutuhan berkuasa (need for power). Jika kebutuhan seseorang sangat kuat, dampaknya ialah motivasi orang tersebut untuk menggunakan perilaku yang mengarah ke pemuasan butuhannya. Selanjutnya Mc Clelland dalam Sigit (2003) menyatakan bahwa; ada korelasi tinggi rendahnya motivasi berprestasi dengan tinggi rendahnya keberhasilan usaha.

\section{Faktor-Faktor yang Mempengaruhi Kepuasan Kerja}

Menurut Burt dalam Anoraga (2005) menyatakan bahwa; Faktorfaktor yang ikut menentukan kepuasan kerja sebagai berikut :

a. Faktor hubungan antara karyawan, antara lain: hubungan langsung antara manajer dengan karyawan, faktor psikis dan kondisi kerja, hubungan sosial diantara karyawan, sugesti dari teman sekerja, emosi dan situasi kerja.

b. Faktor-faktor individual, yaitu yang berhubungan dengan: sikap, umur dan jenis kelamin".

c. Faktor- faktor luar, yaitu hal-hal yang berhubungan dengan keadaan keluarga karyawan, rekreasi dan pendidikan

Anwar Prabu (2004), mengatakan bahwa faktor-faktor yang mempengaruhi kepuasan kerja adalah:

1. Faktor pegawai, yaitu kecerdasan (IQ), kecakapan khusus, umur, jenis kelamin, kondisi fisik, pendidikan, pengalaman kerja, kepribadian, emosi, cara berpikir, persepsi dan sikap kerja.

2. Faktor pekerjaan, yaitu jenis pekerjaan, struktur organisasi, pangkat (golongan), kedudukan, mutu pengawasan, jaminan finansial, kesempatan promosi jabatan, interaksisosial dan hubungan kerja

Banyak faktor yang mempengaruhi kepuasan kerja karyawan, faktorfaktor itu sendiri dalam peranannya memberikan kepuasan kepada karyawan bergantung pada pribadi masing-masing karyawan. Karyawan satu dengan yang lain akan memiliki faktor yang berbeda yang akan mempengaruhi kepuasan kerjanya. 
Chiselli dan Brown dalam Anoraga (2005) menyatakan bahwa; faktor-faktor yang dapat menimbulkan kepuasan kerja adalah kedudukan, pangkat jabatan, masalah umur, jaminan finansial serta mutu pengawasan. Sementara Anthony dan Anoraga (2005) menyatakan bahwa; ada faktorfaktor internal yang mempengaruhi kepuasan kerja yaitu : "kita harus menyukai pekerjaan kita, kita harus berorientasi mencapai prestasi yang tinggi dan kita harus mempunyai sikap positif dalam menghadapi kesulitan.

Rivai (2004) menyatakan bahwa; faktor-faktor yang biasanya digunakan untuk mengukur kepuasan kerja seorang karyawan adalah: (a) isi pekerjaan, (b) supervisi, (c) organisasi dan manajemen, (d) kesempatan untuk maju, (e) gaji dan keuntungan dalam bidang finansial lainnya seperti adanya insentif, (f) rekan kerja dan (g) kondisi pekerjaan. Selain itu menurut Job Descriptive Index (JDI) faktor penyebab kepuasan kerja adalah (1) bekerja pada tempat yang tepat, (2) pembayaran yang sesuai, (3) orang yang berada dalam pekerjaan yang tepat.

Mathis dan Jackson (2001) menyatakan bahwa; kepuasan kerja mempunyai banyak dimensi yaitu " kepuasan dalam pekerjaan itu sendiri, gaji, pengakuan, hubungan antara supervisor dengan tenaga kerja dan kesempatan untuk maju". Menurut Milton dalam Sigit (2003) "dimensidimensi kepuasan kerja yang diperoleh dari studi dan penelitian adalah:

a. Kerja (work): termasuk minat intrinsik, variasi, kesempatan untuk belajar, kesulitan, banyaknya kegiatan, kesempatan untuk sukses dan penguasaan langkah dan metode

b. Bayaran (pay) : banyaknya bayaran, kalayakan atau adil, dan cara pembayaran

c. Promosi (promotion) : kesempatan untuk promosi, kejujuran dan dasar untuk promosi

d. Pengakuan (recognition) : pujian atas pelaksanaan, penghargaan atas selesainya pekerjaan, dan kritik

e. Kondisi kerja (work condition): jam kerja, istirahat, peralatan, temperatur, ventiasi, kelembaban, lokasi, dan layout fisik.

f. Penyeliaan (supervision): gaya penyeliaan dan pengaruh, teknis penyeliaan, perhubungan kemanusiaan dan keahlian administrasi

g. Teman-pekerja (co-worker): kemampuan, kesukaan menolong dan keramahan.

h. Perusahaan dan manajemen (company and management): perhatiannya terhadap karyawan, bayaran dan kebijakan. 
Dari penelitian-penelitian terungkap bahwa tingginya kepuasan kerja mengakibatkan komitmen dengan organisasi, keterlibatan dengan pekerjaan, perbaikan kesehatan fisik dan mental dan kualitas kehidupan yang lebih baik meskipun diluar pekerjaannya. Sebaliknya, ketidakpuasan kerja dapat mengakibatkan absenteisme, perputaran pekerja, masalahmasalah tenaga kerja, kesusahan, pembentukan seikat sekerja dan suasana yang tidak baik.

Berdasarkan beberapa pendapat yang disampaikan di atas maka dapat disimpulkan bahwa kepuasan kerja yang dirasakan setiap orang sangat berbeda, ada banyak aspek yang mempengaruhinya. Beberapa aspek tersebut sangat penting guna menunjang tercapainya kepuasan kerja. Adanya pemenuhan kebutuhan yang dimiliki seseorang berdampak pada pencapaian nilai kerja seseorang atas pekerjaan yang telah dilaksanakannya.

\section{Hubungan Kepuasan Kerja dengan Organizatioan Citizenship Behavior}

Sikap karyawan yang berkaitan dengan kepuasan kerja dan komitmen organisasi adalah minat utama dalam bidang perilaku organisasi dan praktik manajemen sumber daya manusia. Sikap sejauh ini mempunyai implikasi langsung terhadap kepuasan kerja. Pembahasan kepuasan kerja fokus pada sikap karyawan terhadap pekerjaannya (Luthans, 2006)

Robbins dan Coulter (2010) mengatakan bahwa kepuasan kerja mengacu pada sikap yang lazim ditunjukkan seseorang terhadap pekerjaannya. Seseorang dengan kepuasan kerja yang tinggi memiliki sikap positif terhadap pekerjaannya. Sementara, seseorang yang tidak puas memiliki sikap negatif terhadap pekerjaannya. Ketika membicarakan sikap karyawan, biasanya merujuk pada kepuasan kerja.

Perasaan positif dan senang dalam bekerja merupakan gambaran dari adanya kepuasan kerja. Sebagaimana yang dikemukakan oleh Robbins dan Judge (2008), bahwa istilah kepuasan kerja dapat didefinisikan sebagai suatu perasaan positif tentang pekerjaan seseorang yang merupakan hasil dari sebuah evaluasi karakteristiknya. Seseorang dengan tingkat kepuasan kerja yang tinggi memiliki perasaan-perasaan positif tentang pekerjaan tersebut, sementara orang yang tidak puas memiliki perasaan-perasaan negatif tentang pekerjaan tersebut.

Robbis dan Coulter (2010) mengatakan bahwa ketika karyawan kurang puas dengan pekerjaannya, akan beraksi dengan beragam cara. Misalnya, mengundurkan diri, menggunakan waktu kerja untuk 
kepentingan lain, hanya bekerja kalau diawasi dan lain sebagainya. Perilaku demikian, jelas akan merugikan organisasi tempat mereka bekerja. Jika karyawan menggunakan waktu kerja untuk kepentingan lain berarti menimbulkan pemborosan dari segi waktu, bekerja hanya kalau diawasi juga mengakibatkan efisiensi menjadi rendah. Maka, perlu perhatian untuk menciptakan suasana yang akan memenuhi harapanharapan karyawan sehingga pada ahirnya mereka merasa puas dan bersedia berperilaku melebihi tugas yang ditetapkan organisasi.

Kepuasan kerja adalah istilah yang relatif baru, karena di masa lalu, pilihan pekerjaan biasanya tidak berada di tangan individu, tetapi kebanyakan orang melakukan apa yang dilakukan orangtuanya. Selain itu, kondisi ekonomi dan perubahan sosial membuka kesempatan individu untuk memperoleh pendidikan dan pekerjaan. Pertanyaannya sekarang, tidak hanya sebatas, apakah pekerjaan dapat menghidupi seseorang, tetapi apakah individu merasa terpuaskan oleh pekerjaannya. Semakin bahagia individu pada pekerjaannya, maka yang bersangkutan akan merasa semakin puas. Keyakinan bahwa karyawan yang merasa puas jauh lebih produktif bila dibanding dengan karyawan yang tidak puas telah menjadi prinsip dasar diantara para manajer selama bertahun-tahun (Robbins dan Judge, 2008). Karena karyawan merupakan aset penting bagi perusahaan maka sudah merupakan keharusan bagi manajemen untuk memikirkan cara pemenuhan kebutuhan karyawan supaya mereka melaksanakan pekerjaan dengan kesadaran sendiri, dengan senang hati, bukan karena terpaksa.

Locke (dalam Luthans, 2006) mengatakan bahwa kepuasan kerja adalah keadaan emosi yang senang atau emosi positif yang berasal dari penilaian pekerjaan atau pengalaman kerja seseorang. Secara umum, dalam bidang perilaku organisasi, kepuasan kerja adalah sikap yang paling penting dan sering dipelajari. Robbins dan Judge (2008) mengatakan bahwa karyawan yang puas tampaknya cenderung berbicara secara positif tentang organisasi, membantu karyawan lain dan melewati harapan norma dalam pekerjaan mereka. Selain itu, karyawan yang puas, lebih mudah berbuat lebih dalam pekerjaan mereka sebagai bentuk keinginan merespons pengalaman mereka.

Mengacu pada uraian di atas, dapat diketahui bahwa kepuasan kerja terkait dengan emosi positif individu, yang pada ahirnya dapat menimbulkan konsekuensi positif seperti produktivitas dan juga perilaku Organizational Citizenshi Behavior. Organ (dalam Baron dan Byne, 2005) mengatakan bahwa kondisi suasana hati yang baik akan meningkatkan 
peluang terjadinya tingkah laku menolong orang lain, sedangkan kondisi suasana hati yang tidak baik akan menghambat pertolongan

Baron dan Byne (2005) mengutip berbagai penelitian yang menunjukkan bahwa ketika partisipan penelitian sedang berada pada suasana hati yang positif (sebagai hasil dari mendengarkan rekaman komedi atau menghabiskan waktu di luar rumah pada hari yang menyenangkan), mereka akan lebih mungkin untuk terlibat dalam tindakan prososial untuk menolong orang asing. Secara keseluruhan, berbagai penelitian laboratorium dan lapangan ini secara konsisten mengindikasikan pengaruh yang menguntungkan dari emosi positif pada perilaku prososial.

Seperti yang dikatakan King (2010) bahwa karyawan yang merasakan kepuasan kerja akan memiliki emosi positif atau menjadi bahagia. Tampaknya, perasaan positif akan menaikkan kesediaan untuk bertindak prososial. Emosi seseorang dapat mempengaruhi kecenderungannya untuk menolong. Emosi positif secara umum meningkatkan tingkah laku menolong. Lebih jauh lagi, kebiasaan perasaan positif pada pekerjaan adalah hal untuk memahami apa yang disebut dengan kespontanan organisasi seperti membantu rekan kerja, melindungi organisasi, memberikan saran yang konstruktif, mengembangkan kemampuan diri dalam perusahaan (George dan Brief. Dalam King, 2010)

Robbins dan Coulter (2010) mengatakan bahwa logis apabila menyimpulkan bahwa kepuasan kerja menjadi determinan Organizationa Citizenship Behavior seorang karyawan. Karyawan yang lebih puas akan mengutarakan hal - hal positif tentang perusahaan, membantu rekan lain dan melampauai ekspektasi kerja formal.

Taylor dkk (2009) mengutip berbagai pendapat tokoh yang mengatakan, ada banyak bukti bahwa individu bersedia menolong apabila sedang dalam keadaan good mood, misalnya setelah mendenganrkan musik yang menyenangkan.

\section{KESIMPULAN}

Organisasi yang memiliki karyawan dengan Organizational Citizenship Behavior yang baik, akan mencapai produktifitas yang tinggi. Karyawan dengan Organizational Citizenship Behavior yang baik akan bekerja dengan kesadaran sendiri, bukan karena diawasi atau terpaksa, bersedia membantu rekan kerja yang beban tugasnya banyak/sulit atau berperilaku secara sukarela untuk berkontribusi melebihi tugas dan tanggung jawabnya. Bekerja dengan kesadaran sendiri berarti mencintai pekerjaannya, bekerja dengan senang hati, baik karena pekerjaan itu sesuai 
dengan harapan karyawan atau karena situasi yang mendukung. Perilakuperilaku demikian menggambarkan nilai tambah karyawan yang pada ahirnya akan membantu organisasi untuk mencapai produktifitas yang lebih baik.

Salah satu faktor yang mempengaruhi seseorang untuk berperilaku Organizational Citizenship Behavior adalah rasa puas yang didapat dari pekerjaannya. Seseorang yang merasa puas akan pekerjaannya cenderung memiliki emosi positif atau menjadi bahagia dan perasaan positif akan menaikkan kesediaan untuk bertindak proporsional. Emosi positif secara umum meningkatkan kesediaan membantu orang lain, bekerja melampaui harapan organisasi, memberi sumbangan pemikiran untuk kemajuan organisasi, dimana semuanya itu merupakan bagian dari Organizational Citizenship Behavior.

Maka, untuk dapat memiliki karyawan yang memiliki OrganizationalCitizenship Behavioryang baik, dibutuhkan peranan dari manajemen untuk memahami kebutuhan karyawan. Apabila harapan harapan karyawan seperti lingkungan kerja, keadilan, dukungan atasan, fasilitas dan lain sebagainya sesuai dengan harapan, maka karyawan akan merasa puas dan rasa puas tersebut akan memunculkan kesediaan untuk bekerja melebihi batas-batas yang telah ditetapkan organisasi dimana mereka bekerja.

\section{DAFTAR PUSTAKA}

A.A. Anwar Prabu Mangkunegara., 2004, Manajemen Sumber Daya Manusia Perusahaan, Bandung : PT. Remaja Rosdakarya.

Anoraga. 2005. Psikologi Kerja. Jakarta: Rineka Cipta

Baron,R. A. \& Byne,D. (2005). Psikologi Sosial (10th ed). Jakarta: Erlangga

Gibson, James L., John M. Ivancevich dan James H.Donelly, Je. 2000. Organizations: Behavior, Structure and Process, Boston: McGraw - Hill Companies,Inc.

Hani Handoko. 2001. Manajemen Personalia dan Sumber Daya Manusia,Yogyakarta: BPFE

King, L.A. 2010. Psikologi Umum: Sebuah pandangan apresiatif. Buku 2. Penerjemah: Brian Marwensdy. Jakarta: Salemba Humanika

Luthans, Fred. 2006. Perilaku Organisasi, Edisi Kesepuluh, Alih Bahasa: V.A Yuwono, Yoyakarta: Penerbir ANDI 
Mathis, Robert L. \& Jackson, John H. 2009. Manajemen Sumber Daya Manusia, Jakarta: Salemba Empat, and consequences. California:Sage Publication.

Organ, D. W., Podsakoff, P.M., and Mackenzie, S.B. 2006. Organizational Citizenship Behavior: Its nature, antecedents

Podsakoff. 2000. Organizational Citizenship Behaviors: A Critical Review of the Theoretical and Empirical Literature and Suggestions for Future Research. Journal of Management.

Robbins, Stephen P. 2008. Organizational Behavior (Perilaku Organisasi). Jakarta: Salemba Empat

Robbins dan Judge, 2008. Perilaku Organisasi, Buku 1 Cetakan ke duabelas, Penerjemah: Angelica, D., Cahyani,R., dan Rosyid,A, Jakarta: Salemba Empat

Robbins, S.P., \& Coulter,M. 2010. Manajemen. Edisi Kesepuluh. Jilid 2. Alih Bahasa: Bob Sabran dan Devri Barnadi Putera, Jakarta: Erlangga.

Sumiyarsih, W., Mujiasih, E., \& Ariati, J. April 2012. Hubungan Antara Kecerdasan Emosional dengan Organizational Citizenship Behavior (OCB) Pada Karyawan CV.Aneka Ilmu Semarang. Jurnal Psikologi Undip Vol. 11, No. 1

Soehardi, Sigit., 2003. Perilaku Organisasi. Yogyakarta: BPFE UST.

Suwarno \& Donni Juni Priansa (2011). Manajemen SDM dalam Organisasi Publik dan Bisnis. Bandung: Alfabeta

Taylor, S.E., Peplau, L.A., \& Sears,D.O. 2009. Psikologi Sosial. Edisi Keduabelas, Cetakan Kesatu. Alih Bahasa: Tri Wibowo, B.S. Jakarta: Kencana Prenada Media Grup.

Veithzal Rivai. 2004, Manajemen Sumber Daya Manusia Untuk Perusahaan

Wibowo. (2011). Manajemen Kinerja. Jakarta: Rajagrafindo Persada. 